\title{
NOTE
}

\section{Transfer of tributyltin from parental female to offspring in the viviparous surfperch Ditrema temmincki}

\author{
Madoka Ohji ${ }^{1, *}$, Takaomi Arai ${ }^{1}$, Nobuyuki Miyazaki ${ }^{2}$ \\ ${ }^{1}$ International Coastal Research Center, Ocean Research Institute, The University of Tokyo, 2-106-1 Akahama, Otsuchi, \\ Iwate 028-1102, Japan \\ ${ }^{2}$ Center for International Cooperation, Ocean Research Institute, The University of Tokyo, 1-15-1 Minamidai, Nakano, \\ Tokyo 164-8639, Japan
}

\begin{abstract}
In order to examine the transfer of tributyltin (TBT) from parental females to offspring, TBT concentrations were determined in both parental females and offspring of the viviparous surfperch Ditrema temmincki Bleeker. The TBT concentration in the parental females was $2.8 \pm$ $1.0 \mathrm{ng} \mathrm{g}^{-1}$ wet wt (mean $\pm \mathrm{SD}$ ), and ranged from 2.0 to $4.2 \mathrm{ng} \mathrm{g}^{-1}$ wet wt. In contrast, the TBT concentration in the offspring was $33.7 \pm 5.7 \mathrm{ng} \mathrm{g}^{-1}$ wet wt and ranged from 24.2 to $42.4 \mathrm{ng} \mathrm{g}^{-1}$ wet wt. The offspring had 10 to 16 times higher concentrations of TBT than the parental females. In the parental females, the proportion of TBT was $51.4 \pm 9.3 \%$ of the total butyltin $(\Sigma \mathrm{BTS}=\mathrm{TBT}+\mathrm{DBT}+\mathrm{MBT})$. The proportion of TBT in the offspring was $81.6 \pm 1.6 \%$, and this value was higher than that of the parental females. These results suggest that TBT is transferred from parental females to the young, and that offspring have a lower metabolic capacity to degrade TBT than their parental females, leading to a high accumulation of TBT. Offspring, therefore, have a higher risk of TBT exposure than the parental females when they are in the ovary.
\end{abstract}

KEY WORDS: Tributyltin · Viviparous fish $\cdot$ Transfer $\cdot$ Parental female $\cdot$ Offspring Resale or republication not permitted without written consent of the publisher

\section{INTRODUCTION}

Tributyltin (TBT), which is used mainly as a marine antifouling paint, has been responsible for many deleterious effects on nontarget organisms in the marine ecosystem (World Health Organization 1980, Alzieu 1986, Hall et al. 1988). Numerous studies have been carried out on its toxic effects from the molecular to the population level of marine organisms (Bryan et al. 1986, Jha et al. 2000, Ohji et al. 2002, 2003a,b). Along with the considerable direct effects of TBT, it is also important to gain an understanding of the effects of TBT on the next generation, for example, the transfer of TBT from parent to offspring, in order to better understand the mechanisms behind the bioaccumulation of butyltin compounds (BTs) in the marine ecosystem. However, little information is presently available on TBT transfer in marine organisms from the parental female (Focardi et al. 2000).
The surfperches (Embiotocidae) have the most evolved viviparity among the teleost fishes. The viviparous surfperch Ditrema temmincki Bleeker mainly inhabits sea grass beds and rocky reefs in temperate regions off Japan and the Korean Peninsula (Matsuura 1984, Nakabo 1984). Its mating season lasts for 3 mo, from early September to early December (Nakazono et al. 1981). After the eggs ripen during November and December, parturition occurs during May and June (Nakazono et al. 1981, Tamura et al. 1981). The offspring generally spend several months in the parental female (Tamura et al. 1981). During the considerably long period of gestation (6 mo), nutrients are provided from the parental female to the young (Webb \& Brett 1972). Since TBT has mainly been used in the marine environment, the viviparous surfperch is potentially exposed to TBT throughout its whole life history. During the period in which the offspring are in the parental female, TBT, together with nutrients, may 
transfer to and accumulate in the offspring. Although it is difficult to examine the transfer of TBT from parental females to fetuses in large marine organisms, as previously reported, it is possible to evaluate the mechanism behind the transfer of TBT from parental females to offspring in smaller organisms, such as D. temmincki.

The aim of the present study was to examine the difference in the accumulation pattern of TBT and its derivatives, dibutyltin (DBT) and monobutyltin (MBT), between parental females and offspring in the viviparous surfperch Ditrema temmincki. The results provide some clues to understanding the mechanism behind the transfer of TBT from parental females to offspring in viviparous fish.

\section{MATERIALS AND METHODS}

Five parental females of Ditrema temmincki (total length, TL: 219 to $245 \mathrm{~mm}$; body weight, BW: 179 to $250 \mathrm{~g}$ ) were collected by set net at Otsuchi Bay, Iwate Prefecture, Japan, on July 23, 2003. Offspring (TL: 47 to $59 \mathrm{~mm}$; BW: 0.86 to $1.91 \mathrm{~g}$ ) were taken from these females (Table 1). The number of offspring in each parental female ranged from 17 to 23 individuals. Three lots of 5 individual offspring were kept from each parent analyzed. In order to determine whether BTs in a single offspring could be analyzed, the BT concentrations in a single individual were also analyzed. Three offspring representing 3 lots of 1 individual taken from 1 parental female were analyzed for evaluation. The BT concentrations in each parental female were also analyzed. All samples were stored in a freezer at $-20^{\circ} \mathrm{C}$ until chemical analysis.

The method used for the determination of the BTs in the biological samples was based on that of Ohji et al.

Table 1. Ditrema temmincki. Total length and body weight of both the parental females $(\mathrm{P})$ and offspring $(\mathrm{O})$. Numerical data are means and standard deviations

\begin{tabular}{|lccc|}
\hline Individual & $\begin{array}{c}\text { Total no. of } \\
\text { inds. }(\text { inds. } \times \text { lots })\end{array}$ & $\begin{array}{c}\text { Total length } \\
(\mathrm{mm})\end{array}$ & $\begin{array}{c}\text { Body weight } \\
(\mathrm{g})\end{array}$ \\
\hline Parental female & & & \\
P1 & 1 & 225.0 & 205.7 \\
P2 & 1 & 245.0 & 249.8 \\
P3 & 1 & 227.1 & 201.9 \\
P4 & 1 & 225.5 & 194.3 \\
P5 & 1 & 219.0 & 179.0 \\
Offspring & & & \\
O1 & $15(5 \times 3)$ & $48.1 \pm 0.74$ & $0.94 \pm 0.03$ \\
O2 & $15(5 \times 3)$ & $54.0 \pm 0.65$ & $1.21 \pm 0.05$ \\
O3 & $15(5 \times 3)$ & $58.0 \pm 1.25$ & $1.75 \pm 0.09$ \\
O4 & $15(5 \times 3)$ & $49.6 \pm 0.91$ & $1.01 \pm 0.05$ \\
O5 & $15(5 \times 3)$ & $54.0 \pm 1.36$ & $1.38 \pm 0.09$ \\
O2 $(1$ ind.) & $3(1 \times 3)$ & $53.7 \pm 0.58$ & $1.18 \pm 0.09$ \\
& & & \\
\hline
\end{tabular}

(in press). The concentrations of BTs in this study are expressed as $\mathrm{Sn}^{4+}$ on a wet weight basis for the biological samples. In order to examine the quality of the data obtained by the analytical procedure, the soft tissues of the fish were spiked with $1 \mu \mathrm{g}$ of BTs. The recoveries of TBT, DBT and MBT were 88.9, 85.6 and $100.5 \%$, respectively, and their relative standard deviations (RSD) were $<5 \%$. Furthermore, quality control tests for BTs in the biological samples were carried out using certified reference material (IRMM CRM 477). Our measured values of BTs agreed with the certification values. The detection limits of each BT for a signal-to-noise ratio of 3 were $0.2 \mathrm{ng} \mathrm{g}^{-1}$ wet wt for the biological samples.

A comparison of the BT concentrations between mother and offspring and between 1 individual and 5 individual offspring were carried out using the MannWhitney U-test (Sokal \& Rohlf 1995).

\section{RESULTS AND DISCUSSION}

The total BTs $(\Sigma \mathrm{BTs}=\mathrm{TBT}+\mathrm{DBT}+\mathrm{MBT})$ was $5.3 \pm$ $1.1 \mathrm{ng} \mathrm{g}^{-1}$ wet wt (mean $\pm \mathrm{SD}$ ), and values ranged from 4.2 to $7.0 \mathrm{ng} \mathrm{g}^{-1}$ wet wt $(\mathrm{n}=5)$ in the parental females (Table 2). The TBT concentration in the parental females was $2.8 \pm 1.0 \mathrm{ng} \mathrm{g}^{-1}$ wet $\mathrm{wt}$, ranging from 2.0 to $4.2 \mathrm{ng} \mathrm{g}^{-1}$ wet wt $(\mathrm{n}=5)$ (Fig. 1). In the offspring, the $\Sigma$ BTs was $41.3 \pm 7.2 \mathrm{ng} \mathrm{g}^{-1}$ wet wt, ranging from 29.9 to $51.7 \mathrm{ng} \mathrm{g}^{-1}$ wet wt $(\mathrm{n}=15)$. The TBT concentration in the offspring was $33.7 \pm 5.7 \mathrm{ng} \mathrm{g}^{-1}$ wet wt, ranging from 24.2 to $42.4 \mathrm{ng} \mathrm{g}^{-1}$ wet wt $(\mathrm{n}=15)$. The values of $\Sigma \mathrm{BT}$ and TBT concentrations in offspring were significantly higher than those in the parental females (Mann-Whitney $U$-test, p < 0.005). The $\Sigma$ BT and TBT concentrations in 1 individual were $43.5 \pm 2.0$ and $31.4 \pm 0.8 \mathrm{ng} \mathrm{g}^{-1}$ wet $\mathrm{wt}$, respectively $(\mathrm{n}=3)$ (Table 2$)$. No significant differences were observed in the $\Sigma \mathrm{BT}$ and TBT concentrations between 1 individual and 5 individuals (Mann-Whitney $U$-test, $\mathrm{p}>0.1$ to 0.5 ). This result suggested that BTs could be analyzed in 1 individual only. The $\Sigma$ BTs and TBT were concentrated in offspring 7 to 9 times and 10 to 16 times higher than in the parental female, respectively (Table 2).

In the parental females, the proportion of TBT, DBT and MBT was $51.4 \pm 9.3,20.9 \pm 2.2$ and $27.8 \pm 7.2 \%$ of the $\Sigma$ BTs, respectively (Fig. 2). The proportion of TBT, DBT and MBT in the offspring was $81.6 \pm 1.6,13.0 \pm 0.6$ and $5.3 \pm 1.6 \%$, respectively. The proportion of TBT was higher than that of the parental females. The pr oportion of TBT, DBT and MBT in 1 offspring was 72.1 $\pm 2.6,14.3 \pm 1.2$ and $13.6 \pm 1.7 \%$, respectively. No differences were observed in the proportion of BTs between 1 individual and 5 individuals. This result suggested that BTs could also be analyzed in only 1 individual. 
Table 2. Ditrema temmincki. Butyltin (BT) concentration (ng g ${ }^{-1}$ wet wt) in both the parental females (P) and offspring (O). TBT: tributyltin; DBT: dibutyltin; MBT: monobutyltin; $\Sigma$ BTs: TBT + DBT + MBT. Numerical data are means and standard deviations

\begin{tabular}{|c|c|c|c|c|c|c|c|}
\hline \multirow[t]{2}{*}{ Individual } & \multirow{2}{*}{$\begin{array}{c}\text { Total no. } \\
\text { of inds. (inds. } \times \text { lots) }\end{array}$} & \multirow{2}{*}{ TBT } & \multirow{2}{*}{ DBT } & \multirow{2}{*}{ MBT } & \multirow[t]{2}{*}{$\Sigma \mathrm{BTS}$} & \multicolumn{2}{|c|}{ Ratio of bioaccumulation } \\
\hline & & & & & & TBT & $\Sigma \mathrm{BTs}$ \\
\hline \multicolumn{8}{|c|}{ Parental female } \\
\hline P1 & 1 & 3.6 & 1.1 & 1.1 & 5.8 & - & - \\
\hline P2 & 1 & 2.0 & 1.1 & 1.5 & 4.6 & - & - \\
\hline P3 & 1 & 2.1 & 1.1 & 1.8 & 5.0 & - & - \\
\hline $\mathrm{P} 4$ & 1 & 2.1 & 0.9 & 1.3 & 4.2 & - & - \\
\hline P5 & 1 & 4.2 & 1.3 & 1.5 & 7.0 & - & - \\
\hline \multicolumn{8}{|l|}{ Offspring } \\
\hline $\mathrm{O} 1$ & $15(5 \times 3)$ & $36.4 \pm 1.6$ & $5.7 \pm 0.3$ & $3.6 \pm 1.2$ & $45.7 \pm 2.9$ & $10.0 \pm 0.4$ & $7.9 \pm 0.5$ \\
\hline $\mathrm{O} 2$ & $15(5 \times 3)$ & $32.2 \pm 1.1$ & $4.9 \pm 0.2$ & $1.8 \pm 0.3$ & $38.9 \pm 1.2$ & $16.0 \pm 0.6$ & $8.4 \pm 0.3$ \\
\hline O3 & $15(5 \times 3)$ & $33.7 \pm 1.5$ & $5.2 \pm 0.2$ & $1.4 \pm 0.1$ & $40.2 \pm 1.6$ & $16.0 \pm 0.7$ & $8.1 \pm 0.3$ \\
\hline $\mathrm{O} 4$ & $15(5 \times 3)$ & $25.0 \pm 1.2$ & $4.2 \pm 0.3$ & $1.6 \pm 0.1$ & $30.8 \pm 1.5$ & $12.1 \pm 0.6$ & $7.3 \pm 0.4$ \\
\hline O5 & $15(5 \times 3)$ & $41.3 \pm 0.9$ & $6.9 \pm 0.1$ & $2.7 \pm 0.6$ & $51.0 \pm 0.7$ & $9.9 \pm 0.2$ & $7.3 \pm 0.1$ \\
\hline O2 (1 ind.) & $3(1 \times 3)$ & $31.4 \pm 0.8$ & $6.2 \pm 0.8$ & $5.9 \pm 0.9$ & $43.5 \pm 2.0$ & $15.6 \pm 0.4$ & $9.4 \pm 0.4$ \\
\hline
\end{tabular}

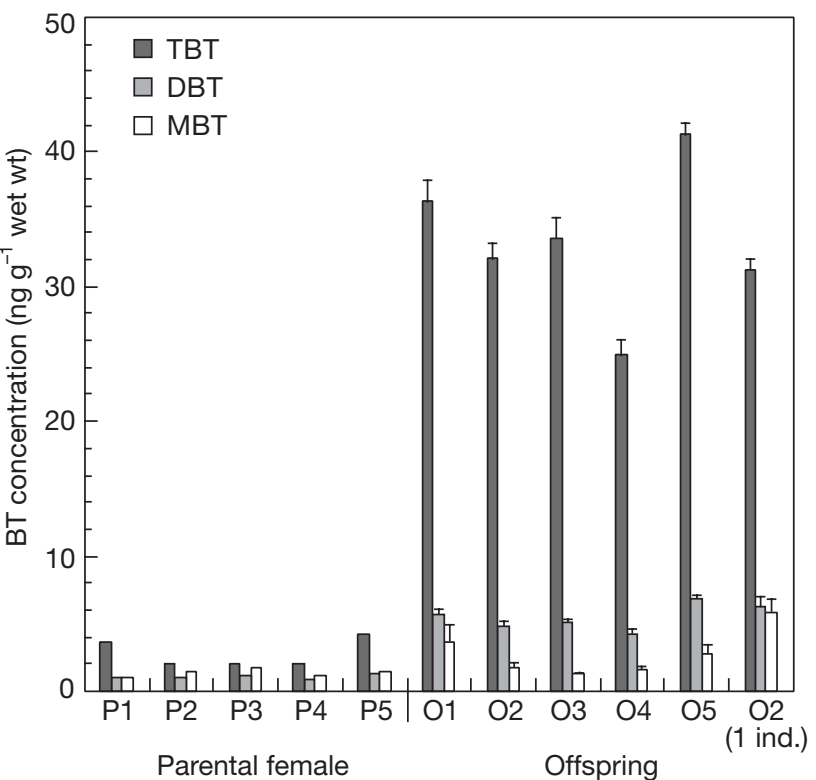

Fig. 1. Ditrema temmincki. Butyltin concentration in parental females and offspring (P: parental female; O: offspring). Error bars are standard deviation

In the present study, the TBT concentrations in the offspring were 10 to 16 times higher than that of the parental females in the viviparous fish. Furthermore, the proportions of TBT in the offspring were significantly higher than those of the parental females. These results suggest that TBT was transferred from the parental females to the offspring and that there was a low metabolic capacity to degrade TBT in offspring, leading to a high accumulation of TBT. Thus, it was concluded that offspring have a higher risk of TBT exposure during their early growth stage than do the parental females. In the viviparous surfperch, the fertilization of eggs occurs in winter, and 6 mo elapse from copulation to the birth of the young (Abe 1969). During this period of gestation,

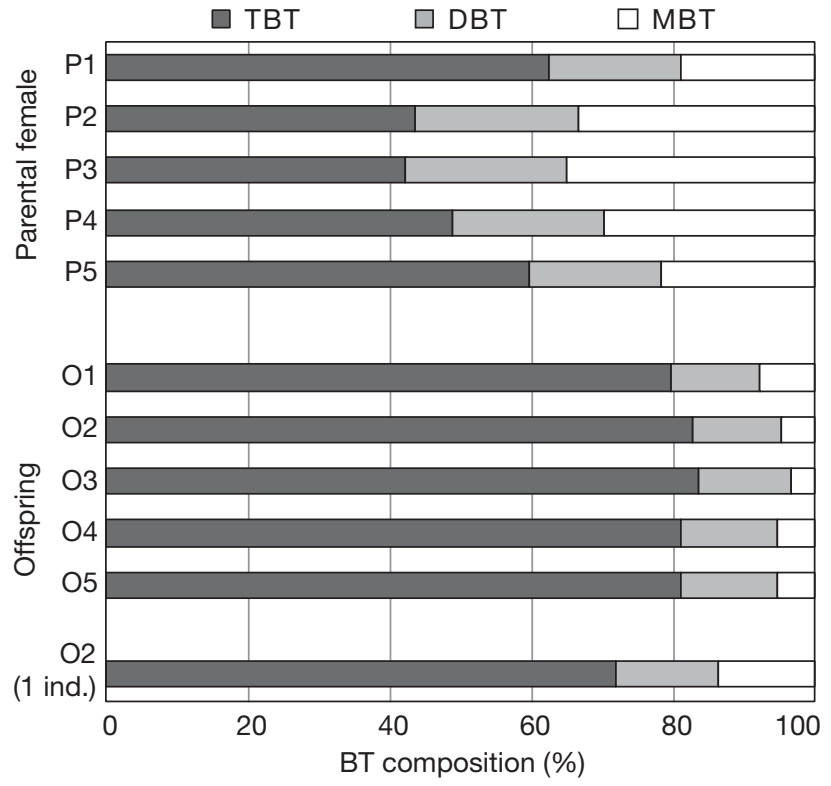

Fig. 2. Ditrema temmincki. Butyltin composition in parental females and offspring (P: parental female; O: offspring)

the supply of materials for growth and respiration and the removal of wastes must be accomplished mainly by diffusion between the ovarian and embryonic blood stream (Webb \& Brett 1972). Since the young stay in the parental female for $6 \mathrm{mo}$, it is considered that TBT, together with nutrients, may be transferred to and accumulate in the offspring.

There is little information on the transfer of BTs from mother to offspring in marine mammals (Focardi et al. 2000). Several studies regarding the transfer from mother to offspring of other chemicals have been conducted, e.g. trace metals and methyl mercury in the harp seal Phoca groenlandica (Wagemann et al. 1988) and organochlorines in the planktonic copepod Acartia tonsa (McManus et al. 1983) and in the bottlenose dol- 
phin Tursiops truncates (Law et al. 1995). McManus et al. (1983) found that in the planktonic copepod A. tonsa, polychlorinated biphenyls (PCBs) in the parental female were released with eggs, which are rich in lipids and provide a sink for hydrophobic compounds such as PCBs and polycyclic aromatic hydrocarbons (PAHs). Di Pinto et al. (1993) also suggested that depuration of PCB via egg production ultimately leads to significantly higher mortality among nauplii. Since TBT is also a hydrophobic compound, it may unite with the lipids in eggs. Therefore, TBT might be transferred to eggs, leading to high mortality of the eggs and/or the young in viviparous fishes such as Ditrema temmincki. It has been reported that TBT causes many deleterious effects to nontarget aquatic life at the early developmental stage (Ohji et al. 2002, 2003a,b). Some information is available on the effects of TBT in marine fishes (Fent \& Meier 1992, Grzyb et al. 2003). In the viviparous surfperch, it is possible that TBT affects survival and growth during the early growth stage of the offspring while they are in the parental female.

In conclusion, our results suggest that TBT is transferred from the parental female to the young and that the offspring have a lower metabolic capacity to degrade TBT than their parental female, resulting in a high accumulation of TBT. Offspring have a higher risk of TBT exposure when in the ovary than the parental female. Therefore, viviparous surfperch are considered to be at a high risk of TBT exposure in the coastal water ecosystem.

Acknowledgements. We are grateful to the staff of the International Coastal Research Center, Ocean Research Institute, The University of Tokyo, for their support of the sample collection. The present study was partially supported by Grantsin-Aid from the Ministry of Education, Culture, Sports, Science, and Technology, Japan (No. 12NP0201).

\section{LITERATURE CITED}

Abe Y (1969) Systematics and biology of the two species of embiotocid fishes referred to the genus Ditrema in Japan. Jpn J Ichthyol 15:105-121

Alzieu C (1986) TBT detrimental effects on oyster culture in France. Evolution since antifouling paint regulation. In. Proceedings of the organotin symposium, oceans ' 86 conference, Washington 23-25 Sep 1986. 4:1130-1134

Bryan GW, Gibbs PE, Hummerstone LG, Burt GR (1986) The decline of the gastropod Nucella lapillus around southwest England: evidence for the effect of tributyltin from antifouling paints. J Mar Biol Assoc UK 66:611-640

Di Pinto ML, Coull C, Chandler GT (1993) Lethal and sublethal effects of the sediment-associated PCB Aroclor 1254 on a meiobenthic copepod. Environ Toxicol Chem 12: 1909-1918

Fent K, Meier W (1992) Tributyltin-induced effects on early life stages of minnows, Phoxinus phoxinus. Arch Environ Contam Toxicol 22:428-438
Focardi S, Corsolini S, Aurigi S, Pecetti G, Sanchez-Hernandez JC (2000) Accumulation of butyltin compounds in dolphins stranded along the Mediterranean coasts. Appl Organometal Chem 14:48-56

Grzyb K, Rychlowski M, Biegniewska A, Skorkowski EF (2003) Quantitative determination of creatine kinase release from herring (Clupea harengus) spermatozoa induced by tributyltin. Comp Biochem Physiol C 134:207-213

Hall LW, Bushong SJ, Ziegenfuss MC, Johnson WE, Herman RL, Wright DA (1988) Acute and chronic effects of tributyltin on a Chesapeake Bay copepod. Environ Toxicol Chem 7:41-46

Jha AN, Hagger JA, Hill SJ, Depledge MH (2000) Genotoxic, cytotoxic and developmental effects of tributyltin oxide (TBTO): an integrated approach to the evaluation of the relative sensitivities of two marine species. Mar Environ Res 50:565-573

Law RJ, Allchin CR, Morris RJ (1995) Uptake of organochlorines (chlorobiphenyls, dieldrin; total PCB \& DDT) in bottlenose dolphins (Tursiops truncatus) from Cardigan Bay, West Wales. Chemosphere 30:547-560

Matsuura K (1984) Family Monacanthidae. In: Masuda H, Amaoka K, Araga C, Ueno T, Yoshiro T (eds) The fishes of the Japanese Archipelago. Tokai University Press, Tokyo, p 345-347

McManus GB, Wyman KD, Peterson WT, Wurster CF (1983) Factors affecting the elimination of PCBs in the marine copepod Acartia tonsa. Estuar Coast Shelf Sci 17:421-430

Nakabo T (1984) Family Embiotocidae. In: Masuda $H$, Amaoka K, Araga C, Ueno T, Yoshiro T (eds) The fishes of the Japanese Archipelago. Tokai University Press, Tokyo, p 184-185

Nakazono A, Takeda Y, Tsukahara H (1981) Mating habits of the surfperch, Ditrema temmincki. Jpn J Ichthyol 28: $122-128$

Ohji M, Arai T, Miyazaki N (2002) Effects of tributyltin exposure in the embryonic stage on sex ratio and survival rate in the caprellid amphipod Caprella danilevskii. Mar Ecol Prog Ser 235:171-176

Ohji M, Arai T, Miyazaki N (2003a) Chronic effects of tributyltin compounds on the caprellid amphipod Caprella danilevskii. Mar Pollut Bull 46:1263-1272

Ohji M, Arai T, Miyazaki N (2003b) Timing of sex disturbbance caused by tributyltin exposure during the embryonic stage in the caprellid amphipod, Caprella danilevskii. J Mar Biol Assoc UK 83:943-944

Ohji M, Arai T, Miyazaki N (in press) Differences of tributyltin accumulation on the masu salmon Oncorhynchus masou between sea-run and freshwater-resident types. J Fish Biol

Sokal RR, Rohlf FJ (1995) Biometry, 3rd edn. WH Freeman, New York

Tamura E, Honma Y, Kitamura Y (1981) Seasonal changes in the thymus of the viviparous surf perch, Ditrema temmincki, with special reference to its maturity and gestation. Jpn J Ichthyol 28:295-303

Wagemann R, Stewart REA, Lockhart WL, Stewart BE (1988) Trace metals and methyl mercury: associations and transfer in harp seal (Phoca groenlandica) mothers and their pups. Mar Mamm Sci 4:339-355

Webb PW, Brett JR (1972) Respiratory adaptations of prenatal young in the ovary of two species of viviparous seaperch, Rhacochilus vacca and Embiotoca lateralis. J Fish Res Board Can 29:1525-1542

World Health Organization (1980) Tin and organotin compounds: a preliminary review. Environmental Health Criteria 15, WHO, Geneva 